Vol 1. No 2. November 2021, e-ISSN : 2807-1670 | p-ISSN : 2807-2316

\title{
UPAYA MENINGKATKAN HASIL BELAJAR BAHASA INDONESIA PADA KEMAMPUAN BERPIDATO PERSUASIF DENGAN TINGKAT PERCAYA DIRI SISWA KELAS 9 SMPN 22 JAKARTA BARAT
}

INNEKE IRIANI MALAU

SMPN 22 Jakarta Barat

Email : Inneke_malau@yahoo.com

\begin{abstract}
ABSTRAK
Penelitian ini bertujuan untuk meningkatkan hasil belajar kemampuan berpidato persuasif dengan tingkat percaya diri pada mata pelajaran bahasa Indonesia untuk kelas IX SMP Negeri 22 Jakarta Barat tahun pelajaran 2021/2022. Penelitian ini merupakan penelitian tindakan kelas (PTK). Subjek dalam penelitian ini yaitu siswa kelas IX SMP Negeri 22 Jakarta Barat tahun ajaran 2021/2022 berjumlah 34 siswa. Prosedur penelitian ini dilakukan melalui empat tahapan yaitu: (1) perencanaan, (2) pelaksanaan, (3) pengamatan dan (4) refleksi. Penelitian ini dilaksanakan melalui 3 (tiga) siklus terdiri dari siklus I dan siklus II. Hasil penelitian ini menunjukkan bahwa tingkat percaya diri berpengaruh terhadap hasil belajar bahasa Indonesia khususnya kemampuan berpidato persuasif pada siswa kelas IX SMP Negeri 22 tahun ajaran 2021/2022. Dari hasil análisis siklus I diperoleh nilai rata-rata 58,69 dengan persentase ketuntasan 70\%. Pada siklus II diperoleh nilai rata-rata adalah 74,59 dengan persentase ketuntasan $84,29 \%$. Hal ini menunjukkan bahwa siswa belum sepenuhnya mencapai ketuntasan belajar. Pada siklus III, ada peningkatan, peningkatan untuk siklus III dengan nilai rata-rata 83,99 atau sudah termasuk kriteria sangat baik dengan persentase ketuntasan mencapai 90,67\%. Hal ini menunjukkan bahwa adanya peningkatan nilai rata-rata dan presentase nilai ketuntasan belajar pada siklus III, karena 3 (tiga) kriteria ini sudah memenuhi kriteria ketuntasan maka penelitian ini diselesaikan di siklus III.
\end{abstract}

Kata Kunci: Hasil Belajar, Kemampuan Berpidato Persuasif dan Tingkat Percaya Diri

\begin{abstract}
The goal of this study is to develop persuasive speech skills and confidence in the Indonesian language subject for class IX of SMP Negeri 22 West Jakarta in the 2021/2022 academic year. This is a classroom action research study (CAR). The participants in this study were 34 students in grade IX from SMP Negeri 22 West Jakarta during the academic year 2021/2022. This study was classified into four stages: (1) preparation, (2) implementation, (3) observation, and (4) reflection. The study was divided into three (three) cycles: cycle I, cycle II, and cycle III. The findings of this study show that self-confidence has an impact on Indonesian students' learning outcomes, particularly their capacity to deliver compelling speeches in class IX at SMP Negeri 22 during the 2021/2022 academic year. The average value of 58.69 was calculated from the results of the first cycle analysis, with a degree of completeness of $70 \%$. The average value was 74.59 in the second cycle, with an 84.29 percent completion rate. This indicates that students have not yet attained full mastery of their subject matter. Cycle III saw a rise, with an average value of 83.99 or already being included in very good criteria with a percentage of completion of 90.67 percent. This demonstrates that the average value and percentage of mastery learning scores increased in cycle III, and this research is completed in cycle III because these 3 (three) criteria matched the criteria for completeness.
\end{abstract}

Keywords : Learning Outcomes, Persuasive Speech Ability, and Confidence Level

\section{PENDAHULUAN}

Bahasa berfungsi sebagai alat komunikasi utama yang paling efektif. Melalui bahasa seseorang dapat melakukan interaksi sosial atau melakukan pertukaran informasi dalam berbagai aspek dan disipilin ilmu. Guru sebagai pelaksana di lapangan menjadi garda terdepan untuk melakukan perbaikan dengan berbagai cara. Salah satunya melalui pembelajaran bahasa 
di sekolah karena melalui pembelajaran tersebut siswa dapat memperoleh berbagai pengetahuan tentang bahasa dan penggunaannya. Pemerintah khususnya pendidik mengharapkan bahasa Indonesia menjadi tuan rumah di negeri sendiri, tugas guru Bahasa Indonesia sebagai garda terdepan memiliki tanggung jawab yang besar untuk meningkatkan kemampuan siswa dalam penggunaan bahasa Indonesia, untuk itu guru bahasa Indonesia harus membuka diri terhadap perkembangan zaman di tengah maraknya penggunaan bahasa asing.

Keterampilan berbicara merupakan salah satu elemen dalam kemampuan berbahasa. Keterampilan berbicara ini yang harus dikuasai salah satunya adalah kemampuan berpidato persuasif. Hal ini sangat berguna baik di lingkungan sekolah maupun di luar sekolah. Di dalam berpidato persuasif tingkat percaya diri seseorang sangat berperan, ketika seorang berpidato selain penguasaan materi dalam pidatonya, tingkat percaya diri sangat membatu dalam penyampaian materi pidato. Pentingnya seseorang khususnya siswa karena dengan memiliki kepercayaan diri yang baik siswa dapat mengaktualisasikan diri pada berbagai kegiatan dan berbagai hal.

Aktualisasi diri adalah kemampuan seseorang untuk menemukan dan mengembangkan potensi yang dimiliki. Kepercayaan diri merupakan aspek yang sangat penting bagi sesorang untuk dapat mengembangkan potensinya. Jika seseorang memiliki bekal kepercayaan diri yang baik, maka individu tersebut dapat mengembangkan potensinya dengan mantap. Namun jika seseorang memiliki kepercayaan diri rendah, maka individu tersebut cenderung menutup diri, mudah frustasi ketika menghadapi kesulitan, canggung dalam menghadapi orang, dan sulit menerima realita dirinya bahkan tidak dapat tampil di depan orang banyak. Dengan kepercayaan diri saat maju di depan kelas, dapat meningkatkan keberanian siswa dalam berpidato, menjawab pertanyaan, mempunyai penampilan diri yang baik, dan mampu mengendalikan perasaan.

Memiliki kepercayaan diri yang tinggi dalam diri siswa dapat membantu mencapai prestasi dan hasil belajar yang lebih baik lagi. "Sikap mental optimisme dari kesanggupan anak terhadap kemampuan diri untuk menyelesaikan segala sesuatu dan kemampuan diri untuk melakukan penyesuaian diri pada situasi yang dihadapi". Sikap optimisme inilah yang menjadikan orang itu percaya terhadap dirinya (Surya, 2007: 56).

Dalam pembelajaran Bahasa Indonesia khususnya di SMPN 22 peneliti merasa dan melihat minat siswa yang sangat rendah. Berdasarkan hasil evaluasi dalam keterampilan berbicara khususnya kemampuan berpidato persuasif hasilnya masih di bawah rata-rata KKM yang ditetapkan di SMPN 22 Jakarta, sehingga guru bahasa Indonesia harus terus mengembangkan diri, dan berusaha menggunakan berbagai cara agar dapat menarik perhatian dan minat peserta didik di SMPN 22 Jakarta, dengan belajar dan menggunakan Bahasa Indonesia di kehidupannya, karena belajar merupakan mekanisme di mana seseorang menjadi anggota masyarakat yang berfungsi secara kompleks, meliputi; skill, pengetahuan, attitude (perilaku), dan nilai-nilai yang diperlukan oleh manusia. Kemampuan-kemampuan tersebut diperoleh peserta didik dari: (1) stimulus dan lingkungan, dan (2) proses kognitif (Gagne 1972).

Berkaitan dengan tingkat percaya diri maka lingkungan sekolah merupakan salah satu faktor yang memiliki peran dalam menumbuhkan kepercayaan diri siswa. Di sekolah siswa dapat dibina tingkat kepercayaan dirinya dengan melihat kemajuannya dalam berprestasi baik bidang akademik maupun non akademik. Contoh: berprestasi di bidang akademik yaitu anak meraih juara di kelas, sedangkan yang non akademik yaitu anak mengikuti lomba-lomba yang diadakan di lingkuingan di mana anak didik tinggal. Misalnya lomba pidato dalam perayaan tujuh belas Agustus atau kegiatan keagamaan seprti lomba ceramah dan memberikan sambutan yang diadakan di sekitar rumah siswa.

Anak harus memperoleh kesan bahwa dirinya diakui dan dihargai di lingkungan dimana dia tinggal, bahkan bila perlu bentuk penghargaan yang diberikan berupa hadiah sederhana yang bisa membangun kepercayaan diri anak untuk berprestasi dan dapat menimbulkan keinginan untuk selalu berusaha mencapai kemajuan atau prestasi baru.

Namun, kenyataannya banyak siswa SMPN 22 sangat kesulitan berbicara ketika disuruh 
untuk mewakili teman berbicara di depan kelas. Berpidato atau bahkan memberi sambutan pada acara-acara tertentu. Di kelaspun bayak siswa yang tidak mampu dan menolak jika disuruh tampil. Terkadang siswa mengatakan bahwa Ia tidak percaya diri untuk tampil di hadapan teman-temannya.

Menumbuhkan kepercayaan diri siswa tidaklah mudah, hal ini membutuhkan dorongan, motivasi dan perhatian dari teman, keluarga, maupun guru di SMPN 22 Jakarta . Sebagai pendidik dituntut untuk tanggung jawab yang besar dalam menyalurkan ilmu pengetahuan yang sudah dimilikinya kepada siswa. Guru perlu melihat jauh dan terpanggil untuk mempersiapkan peserta didiknya agar dapat berkomunikasi dengan orang lain dalam berbagai macam dan situasi sosial.

Berkaitan dengan hal ini maka siswa di SMPN 22 perlu mendapat banyak latihan berpidato yaitu dengan menggunakan lafal yang jelas, dalam pemilihan kosa kata dan penggunaan struktur kalimat ketika membawakan pidato persuasif dengan lancar, begitu juga dalam penguasaan materi, gerak-gerik dan mimik yang disesuaikan dengan materi pidato yang dibawakan. Hal ini tentunya ini ada hubungannya dengan tingkat percaya diri yang dimiliki siswa ketika tampil berpidato di depan kelas sehingga tidak kesulitan mengungkapkan pendapatnya secara lisan. Dengan latihan-latihan seperti yang sudah disebutkan di atas yaitu melafalkan dengan jelas, mampu memilih kosa kata dan strukutur kalimat, daya pengaruh dalam berpidato persuasif, kelancaran berpidato, penguasaan materi berpidato, bahkan mimik dan gerak-gerik yang terlihat sangat kaku dan sangat ketakutan dapat teratasi. Namun, praktik tidak semudah teori masih banyak siswa ketika ditanya mereka mengatakan sangat tidak percaya diri karena merasa tidak bersemangat, tidak dapat mengatasi rasa takut karena ketidakmampuan untuk tampil, tidak dapat mengembangkan kreatifitasnya ketika berada di depan kelas, bahkan merasa tidak mampu untuk mengeluarkan kata-kata.

Seiring dengan masalah tersebut yaitu sulitnya siswa SMPN 22 memiliki keterampilan berbicara dalam hal ini kemampuan berpidato persuasif dan nilai dibawah KKM dengan tingkat percaya diri yang masih rendah, maka untuk mengatasinya peneliti melakukan Penelitian Tindakan Kelas (PTK) yaitu Upaya Meningkatkan Hasil Belajar Bahasa Indonesia pada Kemampuan Berpidato Persuasif dengan Tingkat Percaya Diri Siswa kelas IX di SMPN 22 Jakarta Barat.

\section{METODE PENELITIAN}

Penelitian Tindakan Kelas ini dilaksanakan di SMP negeri 22 Jakarta Barat. Penelitian dilaksanakan pada Semester I Tahun Pelajaran 2021/2022 selama 3 bulan yakni bulan Septemberr sampai dengan Desember 2021. Subyek Penelitian Tindakan Kelas adalah siswa SMP Negeri 22 Jakarta Barat kelas IX semester I (satu) Tahun pelajaran 2021/2021 dan guru Bahasa Indonesia kelas IX disebut subyek pokok, sedangkan guru Bahasa Indonesia lain yang terlibat sebagai peer collaboration disebut subyek pendukung. metode yang digunakan dalam penelitian ini adalah Tindakan Kelas (PTK) atau Classsroom Action Research yang bertujuan untuk memperbaiki efektivitas dan Efisiensi proses pembelajaran. dalam rangka memperbaiki pembelajaran di kelas. Dalam penelitian ini ada dua tindakan yang kelas yang yang di ambil yaitu aktivitas tindakan dan aktivitas penelitian. Tindakan ini dilakukan kepada orang yang sama dan bekerja sama dengan kolaborator. Penelitian Tindakan Kelas merupakan suatu pencermatan terhadap kegiatan belajar berupa sebuah tindakan, yang sengaja dimunculkan .Tindakan tersebut diberikan oleh guru secara bersama, selama tiga siklus

Sebagai alat ukur maka instrument penelitian yang digunakan oleh peneliti adalah instrument tes kemampuan pidato dan instrument Tingkat percaya diri dilengkapi dengan Kuesioner, lembar wawancara, observasi, dan interview. Penelitian tindakan ini berupa jenis kualitatif, teknik yang dilakukan dengan: data note (seperti melakukan observasi dan berpidato), wawancara, dokumentasi, adapun alat pengumpulan data melalui aspek yang berkenaan dengan tingkat percaya diri, aspek yang berkaitan dengan kemampuan berpidato persuasif, observasi, wawancara, pidato perorangan. 


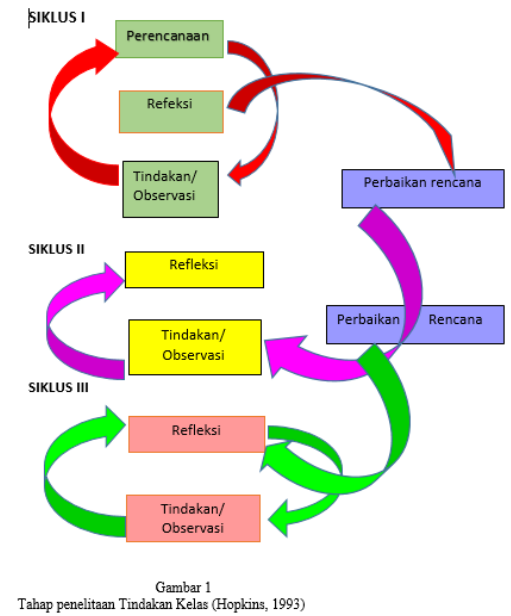

Gambar 1: Desain Penelitian Tindakan Kelas

\section{HASIL DAN PEMBAHASAN}

Kondisi awal merupakan kondisi kemampuan berpidato dengan bahasa Indonesia siswa kelas IX SMP N 22 Jakarta Barat yang diketahui dengan kemampuan berpidato dengan tingkat percaya diri dinyatakan dalam bentuk hasil belajar siswa melalui observasi pada pelaksanaan pembelajaran dan pelaksanaan teks sebelum dilakukan Tindakan Kelas (PTK). Penilaian awal untuk mengetahui keberhasilan pembelajaran dengan mendata nilai bahasa Indonesia (pidato persuasive) sebelum Penelitian Tindakan Kelas dilaksanakan , dengan tes berpidato, mendata hasil belajar siswa sebelumnya dari hasil analisis rata-rata kelas 53,16,distribusi nilai lebih banyak mendapat nilai di bawah 60 dari seluruh siswa satu kelas 50\% nilai siswa yang di bawah kriteria Ketuntasan Minimal (KKM) dan ada $36 \%$ yang dinyatakan mampu melampaui KKM, siswa yang mampu melampaui KKM dinyatakan tuntas belajarnya sedangkan siswa yang nilainya belum mencapai KKM dinyatakan belum tuntas.

Berdasarkan hasil tersebut di atas dapat diketahui bahwa masih terdapat 25 siswa yang merasa kesulitan dan tidak bersemangat dalam pelajaran Bahasa Indonesia, hal ini tentunya perlu evaluasi dengan mencari kesulitan yang dialami siswa dalam berpidato untuk dapat membangkitkan minat siswa dalam belajar bahasa Indonesia untuk itu percaya diri sis wa harus ditingkatkan agar siswa diharapkan dapat berubah dalam belajar bahasa Indonesia/berpidato.

\section{SIKLUS I}

Dimulai dari Pertemuan siklus 1 pertemuan pertama, adalah pertemuan awal dalam proses belajar mengajar yang berlangsung selama 70 menit. Proses belajar mengajar ini menggunakan Tingkat percaya diri. Hasil catatan pelajaran pertemuan pertama disajikan pada lampiran dapat dirangkum sebagai berikut: Siswa diberikan tes Teks kemampuan berpidato, Siswa memperhatikan penjelasan awal mengenai teks pidato persuasif yang diberikan, Guru menentukan atau mengontrol waktu kegiatan berpidato, Siswa memperhatikan teks pidato berupa vidio (Vidio Pidato Pesuasif) dengan seksama, siswa mencatat hal-hal penting dalam teks Pidato, siswa menjawab pertanyaan tentang pidato, guru dan siswa mengoreksi jawaban secara bersama-sama,siswa menghitung skor jawaban sendiri, guru dan siswa melakukan diskusi mengenai kesulitan yang dialami.

Siklus I pertemuan ke-2 Kegiatan yang dilakukan sama dengan kegiatan yang dilakukan pada pertemuan pertama atau sesuai pada rencana pembelajaran yang telah disusun sebelumnya. Karena siswa belum memiliki tingkat percaya diri maka kolaborator memberikan penjelasan ulang mengenai cara menumbuhkan percaya diri bagaimana membuat tingkat percaya diri tinggi dan siswa mendengarkan penjelasan tersebut yang nantinya akan dipraktikkan dalam kemampuan kemampuan berpidato persuasif sehingga termotivasi dan tumbuh kembali kemampuan berpidato persuasive siswa. 
Hasil catatan pembelajaran pertemuan kedua masih disajikan pada lampiran dapat dirangkum sebagai berikut: Siswa diberikan teori berpidato dengan kegiatan (berlatih dengan teman, memberikan tanggapan, pemecahan masalah yang terdapat dalam berpidato persuasif). berdiskusi tentang teks pidato dengan Tingkat percaya diri, siswa memperhatikan penjelasan awal mengenai kemampuan berpidato persuasif dengan tingkat Percaya Diri, guru menentukan atau mengontrol waktu kegiatan berpidato persuasif, siswa memahami teks berpidato persuasif dengan seksama siswa mencatat hal-hal penting yang terdapat pada tingkat percaya diri , siswa mencatat hal-hal yang berkenaan dengan teknik berpidato persuasive yang baik dan tepat, guru dan siswa melakukan evaluasi dengan siswa untuk mengoreksi unjuk kerja (berpidato) secara bersama-sama, siswa menghitung skor jawaban masing-masing siswa, guru dan siswa melakukan diskusi mengenai kesulitan yang dialam dalam berpidato persuasif dengan tingkat percaya diri.

Observasi terhadap guru untuk mengetahui kemampuan guru dalam menerapkan kemampuan berpidato dengan tingkat percaya diri ditinjau dari tujuh indicator yaitu: (1) kelengkapan persiapan mengajar, (2) Apersepsi, (3) Penguasaan Bahan Ajar, (4) Penguasaan kelas, (5) Penggunaan alat peraga, (6) Memberikan penguatan, (7) Mengadakan evaluasi. Sedangkan kriteria penilaian dibedakan menajdi 5 yaitu sangat baik, baik, cukup, kurang baik, tidak baik,

Hasil pengamatan aktifitas belakar siswa pada pembelajaran (lihat Tabel 2) yang terdiri dari siswa belum memaksimalkan potensi diri ada 18 siswa atau $61,4 \%$, melakukan perubahan cara berpidato persuasif 17 siswa atau 56,8 \%(46,8 \%), keseriusan dalam berpidato persuasif 15 siswa atau 52,9\%, aktif bertanya ketika guru sedang menerangka 12 siswa atau 48,3\% dan aktif menjawab jika guru melontarkan pertanyaan 13 siswa atau 47,7\%.

Hasil belajar yang dicapai siswa setelah Siklus I ini berakhir memperlihatkan perolehan nilai yang berbeda jika dibandingkan dengan kondisi awal sebelum Penelitian Tindakan dilakukan yaitu nilai unjuk kerja kemampuan berpidato persuasive sebelumnya nilai rata-rata diperoleh sebesar 58,69 (48,69) dengan nilai maksimum 80 dan nilai minimum 50 (40), setelah diadakan penelitian siklus I maka nilai rata-rata diperoleh 58,69 dengan nilai maksimum 90,66 dan nilai terendah 40 meski secara klasikal belum mencapai ketuntasan $100 \%$ namun jumlah siswa yang sudah mencapai daya serap meningkat 69 siswa atau ketuntasan belajar pada siklus ini mencapai 70 .

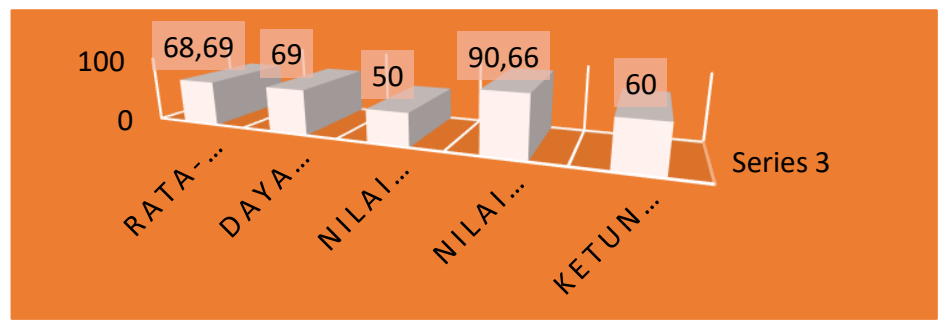

\section{Gambar 2. Grafik diagram batang hasil belajar siswa pada siklus}

\section{SIKLUS II.}

Hasil belajar yang dicapai siswa setelah siklus II berakhir, memperlihatkan perolehan nilai yang yang lebih baik jika dibandingkan dengan kondisi hasil pembelajaran Siklus I ratarata nilai yang diperoleh adalah 74, $59(64,59)$ dengan nilai maksimum 90 (80.00), dan nilai minimum 70 (60.00). Jumlah siswa yang sudah mencapai taraf ketuntasan seluruh siswa atau ketuntasan belajar pada siklus II sebesar 84,29\% (74.29\%.) 
Vol 1. No 2. November 2021, e-ISSN : 2807-1670 | p-ISSN : 2807-2316

Tabel 1. Nilai Rata-rata, Daya Serap, dan Ketuntasan belajar pada Siklus II

\begin{tabular}{|l|l|l|l|l|l|l|}
\hline & $\begin{array}{c}\text { Nilai } \\
\text { Rata-Rata }\end{array}$ & $\begin{array}{c}\text { Daya } \\
\text { Serap }\end{array}$ & $\begin{array}{c}\text { Nilai } \\
\text { Minimum }\end{array}$ & $\begin{array}{c}\text { Nilai } \\
\text { Maksimum }\end{array}$ & KKM & Ketuntasan \\
\hline 1. & 74,59 & $75 \%$ & 70 & 90 & 75 & $84,29 \%$ \\
\hline
\end{tabular}

HASIL BELAJAR BAHASA INDONESIA SISWA

PADACSIKLUS II

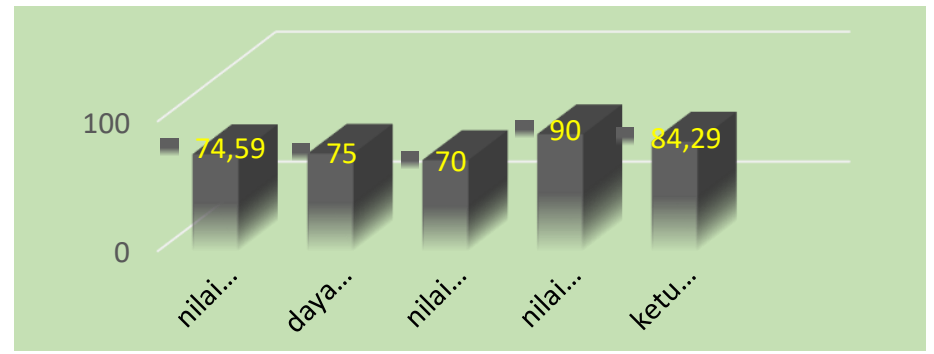

Gambar 3. Hasil Belajar Bahasa Indoenesi Siswa Siklus II

Hasil Refleksi dan observasi terhadap guru dalam pelaksanaan tindakan pertemuan kedua walaupun masih terlihat penggunaan lafal daerah hasil yang diperoleh sebagai adalah . 74, 59 64,59 dengan kategori tuntas 84,29 74,29\%

\section{SIKLUS III}

Pada siklus III menunjukkan, bahwa Siswa lebih aktif dan selalu memberikan respon posistif dalam setiap pembelajaran yang dikembangkan dalam penelitian ini. Aktivitas adalah Berbagai macam kegiatan baik aktivitas fisik maupun psikis, jiwanya bekerja sebanyakbanyaknya atau benyak berfungsi dalam rangka kegiatan belajar mengajar.seperti yang diungkapkan (Rohani 2004) .

Rata-rata nilai Siklus III yang diperoleh adalah 83.99 dengan nilai maksimum 90,67, sedangkan nilai minimum 70.67. jumlah siswa yang sudah mencapai taraf ketuntasan seluruh siswa atau ketuntasan belajar pada siklus III ini sebesar $100 \%$. Siklus III pertemuan kedua sebagai berikut:

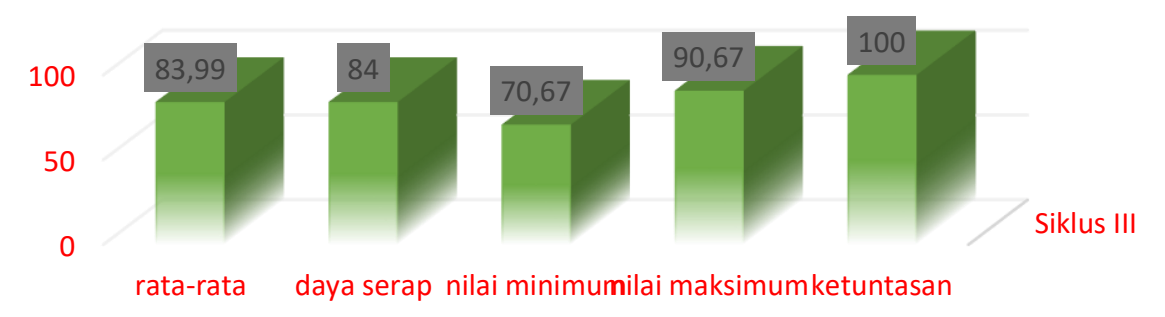

\section{Gambar 4. Grafik tentang hasil Belajar Bahasa Indonesia siswa pada siklus III}

Pembahasan Hasil, berdasarkan kondisi awal siklus 1, siklus II, dan Siklus III sebagai berikut; (1) Materi Pembahasan Kemampuan berpidato Persuasif dengan tingakt percaya diri, dengan membuka kegiatan pembelajaran dengan memberikan motivasi, kemudian dilanjutkan penjelasan mengenai teori berpidato persuasif menggunakan LCD dan PPT. Mengisi kuisioner tingkat percaya diri, menanyakan kepada siswa kendala-kendala yang dihadapi. Seperti yang diungkapkan (Rahmat 2002) pidato persuasif merupakan proses mempengaruhi pendapat, sikap, dan tindakan orang dengan menggunakan manipulasi psikologis, sehingga orang tersebut bertindak atas kehendaknya sendiri untuk menyetujui. Tentunya dalam berpidato persuasif peserta didik harus membentuk percaya diri yang baik 
dan terarah, (De Anjelis, 2002) Untuk dapat membentuk kepercayaan diri pada dasarnya berawal dari keyakinan diri kita sendiri, bagaimana kita dapat menghadapi segala tantangan dalam kehidupan, sehingga kita mampu berbuat sesuatu untuk menghadapi segala tantangan yang ada.

Hasil Belajar yang diperoleh siswa pada setiap akhir Siklus tampak adanya peningkatan yang cukup signifikan, yaitu kenaikan nilai rata-rata siswa, dari Siklus I rata-rata nilai 58,69 menjadi 73,99 (siklus III), daya serap dari 59\% pada siklus I menjadi $74 \%$ pada siklus III, Nilai minimumi 40 dari siklus I menjadi 60.67 pada siklus III, Nilai maksimum 80 pada siklus II menjadi 90,67 pada siklus III, sedangkan ketuntasan belajarnya adalah $60 \%$ pada siklus I menjadi $100 \%$ pada siklus III. Seperti yang diungkapkan oleh Hasil belajar merupakan bagian terpenting dalam pembelajaran. Nana (Sudjana 2009) yang mendefinisikan hasil belajar siswa pada hakikatnya adalah perubahan tingkah laku sebagai hasil belajar dalam pengertian yang lebih luas mencakup bidang kognitif, afektif, dan psikomotorik. Nilai siswa meningkat dipengaruhi oleh keaktifan dalam belajar yang disertai dengan Tingkat Percaya Diri yang tinggi yang dapat berpengaruh terhadap kemampuan siswa dalam berpidato persuasif

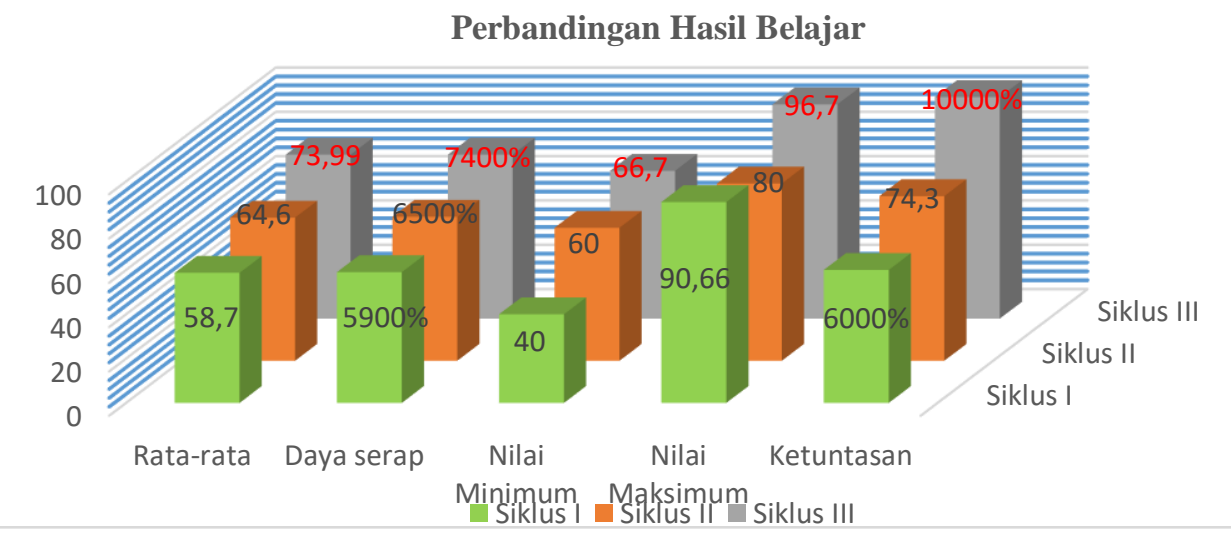

\section{Gambar 5. Perbandingan Hasil Belajar Sisiwa pada Siklus I, II dan Siklus III}

Dari gambar tersebut di atas terlihat nilai rata-rata naik 15,29 poin, daya serap naik 15 pon, ketuntasan belajar naik 40 poin. Peningkatan aktivitas dan perolehan belajar siswa dari siklus I, II dan Ke III didukung oleh adanya perbaikan kinerja guru yang diamati oleh kolaburator, hal ini tentu saja berpengaruh pada kenaikan hasil belajar siswa yang ditunjukkan pada siklus I, II dan siklus III. Rasa percaya diri siswa di sekolah dapat dibangun melalui berbagai macam bentuk kegiatan seperti memupuk keberanian untuk bertanya, peran guru, berlatih diskusi, belajar berpidato (Hakim 2002). Dengan demikian penyampaikan tujuan pembelajaran yang sudah tepat serta menggunakan kemampuan berpidato persuasif dengan tingkat percaya diri tinggi dapat memotivasi siswa utnuk meningkatkan hasil belajar Bahasa Indonesia pada Kompetensi Dasar Pidato Persuasive siswa kelas IX di SMP N 22 Jakarta.

\section{KESIMPULAN}

Hasil Penelitian Tindakan Kelas dapat dapat disimpulkan untuk meningkatkan kemampuan berpidato persuasif, diperlukan Tingkat Percaya Diri. Secara signifikan tingkat percaya diri dapat meningkatkan hasil belajar Bahasa Indonesia, Seperti data berikut . Pada siklus I rata-rata hasil belajar Bahasa Indonesia sebesar 58,69, sedangkan Siklus II 64,59, dan Siklus III 73,99 berarti mengalami kenaikan sekitar 15,33 poin

Keaktifan siswa dalam kegiatan pembelajaran juga mengalami prosentase kenaikan angka dari siklus I, siklus II, dan Siklus III , seperti sikap bertanya, menjawab pertanyaan, memberikan pendapat, berpidato persuasive dengan tingkat percaya diri menggunakan suara jelas, dan memaksimalkan potensi, dapat dilakukan dengan baik, dengan demikian dapat disimpulkan bahwa melalui Tingkat Percaya Diri dapat meningkatkan kemampuan berpidato persuasive dalam pembelajaran Bahasa Indonesia. Pada akhirnya bahwa tingkat percaya diri 
dapat diterapkan dalam pembelajaran Bahasa Indonesia khususnya berpidato persuasif berikutnya.

\section{DAFTAR PUSTAKA}

Arikunto, Suharsimi. (2015). Penelitian Tindakan Kelas. Jakarta: Bumi Aksara

De Angelis, B. 2005. Confidence-Percaya Diri Sumber Sukses dan Kemandirian. (Baty Subakti) .Jakarta: PT Gramedia Pustaka Utama.

Deni, Riana.(2009). Kiat Sukes Membangun Kepercayaan Diri. Diakses dalam: http//www.asmakmalaikat.com (Online 28 April 2018).

Gagne, R. M. (1997). Kondisi Belajar dan Teori Pembelajaran. Terjemahan Munandir. Jakarta: Depdikbud Dirjen Pendidikan Tinggi.

Hakim Thursam.(2005). Mengatasi Rasa Tidak Percaya Diri. Jakarta: Puspa Swara

Hopkins. (1993). Desain Penelitian Tindakan Kelas (Model Ebbut). Yogyakarta : Pustaka Belajar

Lie, Anita.(2003). 1001 Cara Menumbuhkan Rasa Percaya Diri Anak. Jakarta: Elex Media Komputindo.

Rohani, Ahmad.(2004). Pengelolaan Pengajaran. Jakarta: Rineka Cipta.

Sudjana,Nana. (2004). Hasil Proses Belajar Mengajar. Jakarta: Rosda

Sriyatun. (2020). Kumpulan Pidato Sederhana.Jakarta: Media Education

Surya Hendra. (2007). Percaya Diri itu Penting. Jakarta: Elex Media Komputindo

Surya Hendra. (2004). Rahasia Membangun Percaya Diri. Jakarta: Elex Media Komputindo

Yosodipuro,Arif. (2020). Pintar Pidato:Kiat Menjadi Orator Hebat. Jakarta: Gramedia Pustaka Utama. 